\title{
Peningkatan Prestasi Belajar Prakarya pada Materi Pokok Pengolahan Bahan Pangan Buah Menjadi Makanan Melalui Pendekatan Quantum Teaching
}

\author{
Anawati Hidayah \\ SMP Negeri 1 Nusawungu Cilacap \\ Rawabangus, Danasri, Nusawungu, Rawabangus, Danasri, Nusawungu, \\ Kabupaten Cilacap, Jawa Tengah \\ Email: bdmartono7@gmail.com
}

\begin{abstract}
Abstrak
Metode pembelajaran tidak dapat selalu digunakan pada setiap pembelajaran. Seorang guru harus bisa menyajikan pelajaran secara menarik dan menyenangkan. Banyak metode dan media disekitar kita yang dapat digunakan dalam kegiatan belajar mengajar. Tujuannya adalah untuk memberikan pengalaman kepada siswa.Oleh karena itu guru sebagai tenaga pendidik yang profesional dituntut lebih terampil dalam memilih dan menggunakan metode yang tepat agar siswa dapat tertarik dan pencapaian hasil belajar sesuai tujuan pembelajaran. Tujuan Penelitian Tindakan Kelas ini adalah untuk mengetahui pendekatan Quantum Teaching dapat meningkatkan prestasi belajar Prakarya pada materi pokok Pengolahan Bahan Pangan Buah Menjadi Makanan di kelas VII A SMP Negeri 1 Nusawungu Tahun Pelajaran 2016/2017. Kesimpulan Berdasarkan hasil penelitian mengenai pendekatan Quantum Teaching pada mata pelajaran Prakarya materi pokok Pengolahan Bahan Pangan Buah Menjadi Makanan di kelas VII A SMP Negeri 1 Nusawungu Tahun Pelajaran 2016/2017 adalah bahwa pendekatan Quantum Teaching dapat meningkatkan prestasi belajar pada siswa kelas VII A SMP Negeri 1 Nusawungu. Prestasi belajar siswa meningkat ditunjukkan dengan hasil ulangan harian pada masingmasing tahapan. Tingkat ketuntasan pada studi awal 47\%, siklus I 71\%, dan siklus II $88 \%$. Rata-rata hasil ulangan harian juga mengalami peningkatan yaitu 65 pada studi awal, 77 pada siklus I dan 86 pada siklus II. Sehingga terjadi rata-rata peningkatan total prestasi belajar dari kondisi awal ke siklus II 21.
\end{abstract}

Kata Kunci : Quantum teaching, pengolahan bahan pangan buah, prestasi belajar

\begin{abstract}
Learning methods cannot always be used in every learning. A teacher must be able to provide interesting and fun lessons. Many methods and media that discuss about us that can be used in teaching and learning activities. The aim is to provide experience to students. Because professional teacher educators are required to prefer to use and use appropriate methods so that students can be interested and learn the results of learning in accordance with the learning objectives. The purpose of this Classroom Action Research is to discuss Quantum Learning to improve the learning achievements of the Workshop on Fruit Food for Food in class VII A of SMP Negeri 1 Nusawungu in the 2016/2017 Academic Year. Quantum Teaching in Subjects Teaching material Teaching Food Materials Into Food in class VII A SMP Negeri 1 Nusawungu in the 2016/2017 Academic Year is that discussing Quantum Teaching can improve learning in class VII A SMP Negeri 1 Nusawungu. Student learning achievement increases with the results of daily tests at each stage. The completeness rate in the initial study was $47 \%$, cycle I $71 \%$, and cycle II $88 \%$. The average results of daily tests also increased by 65 in the initial study, 77 in the
\end{abstract}


first cycle and 86 in the second cycle. Increase the average increase in total learning outcomes from the initial conditions to the second cycle 21 .

Keywords: Quantum Teaching, Food Processing, Learning Achievement

\section{PENDAHULUAN}

Arikunto (1993: 12) mengemukakan "pembelajaran adalah suatu kegiatan yang mengandung terjadinya proses penguasaan pengetahuan, keterampilan dan sikap oleh subjek yang sedang belajar". Sedangkan menurut Undang-undang Sistem Pendidikan Nasional Nomor 20 tahun 2003 menyatakan bahwa "pembelajaran adalah proses interaksi peserta didik dengan pendidik dan sumber belajar pada suatu lingkungan belajar". Pendidikan adalah usaha sadar dan terencana untuk mewujudkan suasana belajar dan proses pembelajaran agar siswa secara aktif mengembangkan potensi dirinya untuk memiliki kekuatan spiritual keagamaan,pengendalian diri, kepribadian, kecerdasan, akhlak mulia serta ketrampilan yang diperlukan dirinya, masyarakat,bangsa dan Negara (UU No 20 Tahun 2003). Belajar mengajar adalah suatu kegiatan yang bernilai edukatif. Nilai edukatif mewarnai edukasi yang terjadi antara guru dan anak didik. Interaksi yang bernilai edukatif ini dikarenakan kegiatan belajar mengajar yang dilakukan diarahkan untuk mencapai tujuan yang telah dirumuskan sebelum pengajaran dilakukan (Syaiful Bahri Djamarah dan Aswan Zain, 1996;1). Kondisi pembelajaran yang selalu diharapkan haruslah didukung sumber daya manusia dalam bentuk kompetensi guru kelas dalam bidang pendidikan, pengajaran, dan prasarana secara tepat termasuk menggunakan metode yang digunakan. Dengan demikian diharapkan akan terdapat hasil belajar yang semakin meningkat sesuai dengan yang diharapkan, baik oleh tenaga pendidik atau guru maupun yang diharapkan para siswa beserta orang tua atau wali siswa. Kemampuan guru dalam pembelajaran di kelas menjadi hal yang berpengaruh besar terhadap pemahaman materi yang disampaikan oleh guru yang pada akhirnya akan mempengaruhi hasil belajar siswa.

Di SMP Negeri 1 Nusawungu, Kabupaten Cilacap sarana dan prasarana untuk kegiatan belajar mengajar sudah memadai. Guru juga sudah menyampaikan materi pelajaran kepada siswa. Namun, pada saat ini prestasi belajar siswa kelas VII A khususnya pelajaran Prakarya pada materi pokok Pengolahan Bahan Pangan Buah Menjadi Makanan dianggap rendah. Hal ini dapat diketahui dari masih rendahnya nilai ulangan harian, yaitu nilai rata-rata kurang dari 78. Kondisi tersebut terjadi karena dalam proses pembelajaran Prakarya ditemukan bahwa guru masih menggunakan metode ceramah dan kurang memberikan kesempatan kepada siswa untuk mengembangkan dirinya serta tidak 
melibatkan siswa secara penuh dalam proses belajar mengajar sehingga siswa mengalami kesulitan dalam mengerjakan tugas yang diberikan oleh guru. Siswa juga kurang aktif dalam mengikuti pembelajaran sehingga belum tercipta suasana interaktif antara guru dan siswa dalam proses belajar mengajar. Saat ini yang dibutuhkan adalah siswa yang lebih aktif melakukan proses pembelajaran sehingga akan tercapai hasil yang optimal optimal. Siswa harus lebih aktif dalam proses belajar mengajar, serta belajar menemukan sendiri tentang pengetahuan yang belum dimiliki.

Prestasi belajar Prakarya relatif rendah. Menurut pengamatan dan diskusi yang peneliti lakukan bersama dengan rekan guru bahwa kelas VII A dibandingkan dengan kelas lain terlihat sebagian besar siswa kelas VII A prestasi belajar Prakarya masih rendah. Salah satu penyebab rendahnya prestasi belajar Prakarya adalah siswa kurang paham terhadap materi yang diajarkan serta kurang aktif berpartisipasi dalam pembelajaran didalam kelas. Siswa juga kurang tertarik dengan materi yang diajarkan oleh guru, sebab guru tidak melibatkan siswa dengan pengalaman yang dimilikinya. Hal ini ditunjukan dari perolehan nilai rata-rata ulangan harian, yaitu 65. Dari situasi dan kondisi yang demikian itu maka penulis tertarik melakukan penelitian tentang "Peningkatan prestasi belajar Prakarya pada materi pokok Pengolahan Bahan Pangan Buah Menjadi Makanan melalui pendekatan Quantum Teaching di Kelas VII A SMP Negeri 1 Nusawungu Tahun Pelajaran 2016/2017".

Rendahnya prestasi belajar siswa untuk mata pelajaran Prakarya di kelas VII pada umumnya dan kelas VII A khususnya yang ditandai dengan perolehan nilai rata-rata ulangan harian yang paling rendah yaitu kelas VII A dengan jumlah siswa seluruhnya 34 siswa, terdiri atas 17 siswa laki-laki dan 17 siswa perempuan dengan nilai rata-rata 65 . Sangat dimungkinkan adanya masalah dasar yang terkait di dalamnya atas dasar informasi yang diperoleh dari dokumen hasil ulangan harian dapat diidentifikasi masalah yang menjadi faktor penyebab rendahnya prestasi belajar Prakarya di kelas VII A dalam semester I Tahun Pelajaran 2016/2017 adalah :

1. Rendahnya hasil nilai ulangan harian siswa

2. Rendahnya minat belajar siswa

3. Rendahnya pemahaman siswa dalam pemahaman konsep pembelajaran Prakarya

4. Motivasi belajar masih rendah

5. Perhatian siswa terhadap pembelajaran masih kurang

6. Siswa kurang memperhatikan penjelasan guru

7. Konsentrasi belajar Prakarya yang masih rendah 
Terlebih dahulu peneliti akan paparkan kajian teori terkait penelitian ini. antara lain:

\section{Prestasi Belajar}

Menurut Kamus Umum Bahasa Indonesia, pengertian prestasi adalah hasil yang telah dicapai (dari yang telah dilakukan, dikerjakan, dan sebagainya) (2005: 910). Ada yang berpendapat bahwa prestasi belajar adalah hasil yang dicapai seseorang dalam melakukan kegiatan belajar. (Siti Pratini, 2005). Menurut Winkel melalui Sunarto (1996: 162) mengatakan bahwa "prestasi belajar adalah suatu bukti keberhasilan belajar atau kemampuan seorang siswa dalam melakukan kegiatan belajarnya sesuai dengan bobot yang dicapainya". Menurut Abu Ahmadi dan Widodo Supriyono (1990: 130) prestasi belajar merupakan hasil interaksi antara berbagai faktor yang mempengaruhinya baik dari dalam diri (faktor internal) maupun dari luar (faktor eksternal) individu. Dari pengertian di atas dapat diambil kesimpulan bahwa prestasi belajar adalah hasil dari suatu kegiatan seseorang atau kelompok yang telah dilakukan, dikerjakan, diciptakan dan menyenangkan hati yang diperoleh dengan melakukan kegiatan belajar.

\section{Pembelajaran Prakarya}

Prakarya adalah mengembangkan pengetahuan dan melatih keterampilan kecapakan hidup berbasis seni, teknologi, dan ekonomi. Prakarya berasal dari istilah Pra dan Karya. Pra mempunyai makna belum, sedangkan Karya mempunyai makna hasil kerja. Prakarya didefinisikan sebagai hasil kerja yang belum jadi atau masih dalam bahan mentah. Prakarya masih berupa proof of concept atau sebuah prototipe. Prakarya memiliki pengertian ialah keterampilan, hastakarya, kerajinan tangan, ataupun keterampilan tangan. Bahan yang digunakan tersedia secara umum dipasaran, sehingga kita tinggal merangkai ataupun pemanfaatan limbah dan bahan bekas. Prakarya mempunyai peranan penting dalam pengembangan kreatifitas serta mengembangkan menjadi sebuah inovasi baru. Dari definisi di atas dapat disimpulkan bahwa Prakarya adalah ilmu yang mempelajari tentang keterampilan, hastakarya, kerajinan tangan, ataupun keterampilan tangan yang tersusun secara sistematis dan jelas untuk membuat pengembangan kreatifitas siswa serta membuat ivonasi baru. Buah merupakan makanan pelengkap dalam menu makanan sehari-hari kita. Setiap orang menyukai rasa dari buah segar dan menjadikannya makanan favorit. Kandungan nutrisi buah yang merupakan makanan alami sangat baik bagi kebugaran dan kesehatan tubuh kita sehari-hari. Agar tubuh selalu bugar dan sehat, para ahli gizi menyarankan untuk mengkonsumsi buah-buahan setiap hari agar asupan kebutuhan nutrisi cukup bagi kesehatan tubuh kita. Dalam merencanakan pembuatan karya pengolahan harus 
diperhatikan apa hal-hal pokok yang ditugaskan, kemudian merencanakan pembuatannya. Agar suatu produk pengolahan berhasil dengan baik, perlu memperhatikan tahapan / proses pembuatan pengolahan bahan pangan buah menjadi makanan yang sesuai dengan harapan.

\section{Pendekatan Quantum Teaching}

Quantum Teaching menurut pendapat DePorter, Reardon, dan Singer-Nourie (2009) adalah berbagai interaksi yang ada di dalam dan di sekitar momen belajar. Interaksi-interaksi ini mencakup unsur- unsur untuk belajar efektif yang mempengaruhi kesuksesan siswa. Pembelajaran yang menyingkirkan hambatan yang menghalangi proses kegiatan belajar dengan cara sengaja mengggunakan musik/mewarnai lingkungan sekeliling, menyusun bahan pengajaran yang sesuai pengajaran yang efektif dan banyak mengaftifkan siswa.

Anitah (2009) menyatakan istilah quantum secara harfiah berarti "kualitas", mekanis (yang berkenaan dengan gerak). Pendapat lain, kata quantum sendiri berarti interaksi yang mengubah energi menjadi cahaya. Jadi Quantum Teaching adalah menciptakan lingkungan belajar yang efektif, dengan cara menggunakan unsur yang ada pada siswa dan lingkungan belajarnya melalui interaksi yang terjadi di dalam kelas (DePorter, Reardon, \& Singer-Nourie, 2009). Proses belajar mengajar adalah fenomena yang komplek, segala sesuatunya berarti (yang meliputi setiap kata, pikiran, tindakan, dan asosiasi) dan sejauh mana guru merubah lingkungan presentasi, dan rancangan pengajaran, sejauh itu pula proses belajar itu berlangsung. Quantum Teaching bersandar pada konsep "Bawalah mereka ke dunia kita dan antarkan dunia kita ke dunia mereka." Ini merupakan dasar dibalik strategi, model dan keyakinan Quantum Teaching (DePorter, Reardon, \& Singer-Nourie, 2009: 3). Langkah-langkah quantum teaching lebih dikenal lewat akronim TANDUR (Tumbuhkan, Alami, Namai, Demonstrasikan, Ulangi, Rayakan), dimana unsurunsur ini membentuk struktur keseluruhan yang melandasi quantum teaching (Sa'ud, 2010). DePorter, et al. (2009) menyatakan bahwa langkah perencanaan quantum teaching meliputi: Pertama, Tumbuhkan (minat). Sertakan rekan, pikat mereka, puaskan rasa ingin tahu mereka. Kedua, Alami (memberi pengalaman pada siswa). Ketiga, Namai (mengajarkan konsep, keterampilan berfikir dan strategi belajar). Keempat, Demonstrasikan (mengaplikasikan pengetahuan siswa). Kelima, Ulangi (memperkuat hubungan-hubungan saraf memori dalam otak). Keenam, Rayakan (simbol penghormatan). Selanjutnya Dharma (2010) mengungkapkan kelebihan model quantum teaching yaitu: (a) pembelajaran menggunakan model quantum teaching dapat membuat siswa merasa $\underline{\text { nyaman dan gembira dalam belajar, karena model ini menutut setiap siswa untuk selalu }}$ 
aktif dalam proses belajar; (b) penggunaan model quantum teaching dalam proses pembelajaran juga dapat memberikan motivasi pada siswa untuk ambil bagian dalam Kegiatan Belajar Mengajar (KBM) yang berlangsung; (c) adanya kesempatan bagi siswa untuk menunjukkan kemampuannya akan memudahkan guru dalam mengontrol sejauh mana pemerolehan siswa dalam belajar; (d) proses belajar siswa lebih terarah pada materi yang sedang dipelajari karena dikaitkan dengan pengalaman-pengalaman seputar kehidupan siswa sehingga bakat dan inisiatif siswa akan lebih berkembang; (e) penggunaan model quantum teaching yang bersandar pada konsep "bawalah dunia mereka kedunia kita, dan antarkan dunia kita ke dunia mereka", dapat mengubah pola pikir anak didik dari yang sempit menjadi lebih luas dan menyuluruh dalam memandang dan memecahkan masalah yang dihadapi dalam kehidupan. Sedangkan kelemahan model quantum teaching menurut Dharma (2010), yaitu: (a) quantum teaching menuntut profesionalisme yang tinggi dari seorang guru; (b) banyaknya media dan fasilitas yang digunakan alam pembelajaran, metode ini dinilai kurang ekonomis; (c) kesulitan yang dihadapi dalam menggunakan model quantum teaching akan terjadi dalam situasi dan kondisi belajar yang kurang kondusif sehingga menuntut penguasaan kelas yang baik.

\section{METODE PENELITIAN}

Penelitian ini dilakukan di SMP Negeri 1 Nusawungu. Jenis Penelitian ini adalah Penelitian Tindakan Kelas yang dilaksanakan sebanyak dua siklus, masing-masing siklus terdiri dari empat tahap yakni: perencanaan tindakan, pelaksanaan tindakan, observasi, refleksi. Subyek penelitian ini adalah siswa kelas VII A SMP Negeri 1 Nusawungu Kabupaten Cilacap dengan jumlah siswa 34 terdiri dari 17 siswa laki-laki dan 17 siswa perempuan. Alasan memilih kelas VII A sebagai subyek penelitian, karena kondisi siswa kelas VII A dibandingkan dengan kelas yang lain prestasi belajar Prakarya masih rendah. Penelitian tindakan kelas ini dilaksanakan dalam 2 siklus, yang tiap siklusnya dilaksanakan 1 kali pertemuan dengan alokasi waktu 2 x 40 menit tiap pertemuan. Setiap siklus terdiri dari kegiatan yang meliputi perencanaan, pelaksanaan tindakan, observasi, evaluasi, dan refleksi. Pada akhir siklus diadakan tes / evaluasi untuk mengetahui besarnya peningkatan hasil belajar matematika sesuai dengan penelitian. Pada siklus 1, dan 2 digunakan pendekatan Quantum Teaching dan menggunakan prosedur penelitian. 


\section{HASIL DAN PEMBAHASAN}

Pemecahan masalah dalam mengatasi rendahnya prestasi belajar siswa kelas VII A SMP Negeri 1 Nusawungu pada tahun pelajaran 2016/2017 melalui pendekatan Quantum Teaching sebagai upaya untuk meningkatkan prestasi belajar pada mata pelajaran Prakarya, terbukti dapat meningkatkan prestasi belajar siswa.

Tabel 1. Prestasi Belajar Siswa pada Studi Awal, Siklus I dan Siklus II

\begin{tabular}{|l|l|l|r|r|l|l|}
\hline No & Uraian & $\begin{array}{l}\text { Studi } \\
\text { Awal }\end{array}$ & Siklus I & Siklus II & $\begin{array}{l}\text { Total } \\
\text { kenaikan }\end{array}$ & $\begin{array}{l}\text { Persentase } \\
\text { Kenaikan }\end{array}$ \\
\hline 1 & Rata-rata & 65 & 77 & 86 & $\mathbf{2 1}$ & $\mathbf{6 2 \%}$ \\
2 & Siswa yang Tuntas & 16 & 24 & 30 & $\mathbf{1 4}$ & $\mathbf{4 1 \%}$ \\
3 & $\begin{array}{l}\text { Siswa yang tidak } \\
\text { tuntas }\end{array}$ & 18 & 10 & 4 & & $\mathbf{4 1}$ \\
4 & $\begin{array}{l}\text { Persentase siswa yang } \\
\text { tuntas }\end{array}$ & $47 \%$ & $71 \%$ & $88 \%$ & & \\
5 & $\begin{array}{l}\text { Persentase siswa yang } \\
\text { tidak tuntas }\end{array}$ & $53 \%$ & $29 \%$ & $12 \%$ & & \\
\hline
\end{tabular}

Prestasi belajar siswa pada kondisi awal atau pra siklus hanya ada 16 siswa yang tuntas atau sebesar 47\%. Sedangkan pada siklus I meningkat menjadi 24 siswa yang tuntas atau sebesar $71 \%$ dan meningkat $24 \%$ dari studi awal. Nilai rata-rata pada kondisi awal 65 mengalami peningkatan pada siklus I dengan nilai rata-rata 77. Pada siklus II, peneliti melakukan revisi pada RPP dan skenario tindakan. Pada siklus II peneliti memberikan perhatian khusus pada siswa yang masih pasif berdasarkan pengamatan pada siklus sebelumnya. Ketuntasan belajar mengalami peningkatan $17 \%$ dari siklus I, yang semula $71 \%$ menjadi $88 \%$ pada siklus II. Ada 30 siswa mendapatkan nilai diatas KKM pada siklus II dengan nilai rata-rata 86 , sehingga dapat dikatakan bahwa ketuntasan belajar rata-rata pada kondisi awal, siklus I dan siklus II mengalami kenaikan yang sangat signifikan. Secara keseluruhan prestasi belajar siswa dalam kegiatan Penelitian Tindakan Kelas yang dilakukan oleh peneliti sudah mencapai kriteria.

\section{KESIMPULAN}

Berdasarkan hasil penelitian dengan menggunakan pendekatan Quantum Teaching pada mata pelajaran Prakarya di kelas VII A SMP Negeri 1 Nusawungu tahun Pelajaran 2016/2017 maka dapat ditarik kesimpulan bahwa Prestasi belajar siswa meningkat. Hal ini dibuktikan dengan hasil ulangan harian pada masing-masing tahapan. Tingkat ketuntasan pada studi awal sebesar $47 \%$ dan mengalami peningkatan pada siklus I sebesar $71 \%$ serta pada siklus II lebih meningkat lagi menjadi 88\%. Rata-rata hasil ulangan harian juga mengalami peningkatan yaitu 65 pada studi awal, dan meningkat menjadi 77 pada siklus I 
serta mengalami peningkatan sebesar 86 pada siklus II. Sehingga terjadi rata-rata peningkatan total prestasi belajar dari kondisi awal ke siklus II 21.

\section{SARAN}

Pada penelitian selanjutnya perlu di eksplorasi lagi tentang penelitian yang berkaitan tentang pembelajaran diberbagai mata pelajaran dengan pendekatan quantum teaching.

\section{DAFTAR PUSTAKA}

Abu Ahmadi dan Supriyono Widodo. (1990). Psikologi Pendidikan. Jakarta : PT. Rineka.

Adi, S. Pengertian Peningkatan Menurut Ahli. Diunduh 20 Agustus dari http://www.duniapelajar.-com.pengertian-peningkatan-menurut-para-ahli.html.

Ali, Mohamad. (2007). Ilmu dan Aplikasi Pendidikan. Bandung : PT. Imtima.

Anitah, Sri. (2009). Strategi Pembelajaran di SD. Jakarta : Universitas Terbuka.

Dharma, Surya. (2010). Manajemen Kinerja. Yogyakarta : Pustaka Pelajar.

De Porter, Bobby, Mark Reardon, dan Sarah Singer. (2009). Quantum Teaching. Bandung : Kaifa.

Djamarah, Syaiful Bahri. (1994). Prestasi Belajar dan Kompetensi Guru. Surabaya : Usaha Nasional.

Djamarah dan Zain. (1996). Strategi Belajar Mengajar. Jakarta : PT. Rineka Cipta.

http://bahan-membuat.com/search/contoh-prakarya

Musfiqon. (2012). Pengembangan Media dan Sumber Pembelajaran. Jakarta : Prestasi Pustaka.

Paresti, Suci, dkk. (2016). Prakarya (Studi dan Pengajaran). Jakarta : Kemendikbud.

Pratini, Siti. (2005). Psikologi Pendidikan. Yogyakarta : Pustaka Pelajar.

Purwanto. (2008). Metodologi Penelitian Kuantitatif. Yogyakarta : Pustaka Pelajar.

Sagala, S. (2009). Pengertian Pembelajaran. Diunduh 20 Agustus 2016.dari https://trys99.-wordpress.com/2014/08/17/pengertian-pembelajaran-menurut-paraahli/.

Saud, Udin Syaefudin. (2010). Pengembangan Profesi Guru. Bandung : Alfabeta.

Sunarto. (1996). Perkembangan Peserta Didik. Jakarta : Rineka Cipta. 
Suryabrata, Sumadi. (1998). Psikologi Pendidikan. Jakarta : PT. Raja Grafindo.

Trianto. (2010). Corey. (1986). Pengertian Pembelajaran. Diunduh 20 Agustus 2016 dari http://dedi26.blogspot.com/2013/04/pengertian-pembelajaran-menurut-para.html

Undang-undang Nomor 20 Tahun 2003 Tentang Sistem Pendidikan Nasional.

Wartono, dkk. (2004). Materi Integritas Sains. Jakarta : Depdiknas.

WJS. Poerwadarminta. (2005). Kamus Umum Bahasa Indonesia. Jakarta : Balai Pustaka.

W.S. Winkel. (1989). Psikologi pendidikan dan Evaluasi pengajaran. Jakarta : Gramedia. 